\title{
Forest Floor Nutrient Dynamics in Chestnut Plantation Ecosystems
}

\author{
Kyriaki Kitikidou (Corresponding author) \\ Department of Forestry and Management of the Environment and Natural Resources, Democritus University \\ PO box 68200 , Orestiada, Greece \\ Tel: 30-693-204-2106Ｅ-mail: kkitikid@fmenr.duth.gr
}

Athanasios G. Papaioannou

Aristotle University, Greece

Received: August 8, 2011

Accepted: August 25, $2011 \quad$ Online Published: February 2, 2012

doi:10.5539/jas.v4n4p51

URL: http://dx.doi.org/10.5539/jas.v4n4p51

\begin{abstract}
Nutrient content and detrital biomass in the forest floor of a mature chestnut plantation at Karies (Agio Oros mountain, Athos peninsula, northern Greece) was measured in autumn of the year 2010. These measurements were compared to their expected values (bibliography based values). All nutrients storage and organic matter were fairly similar, even though measurements in this study were slightly higher than expected.
\end{abstract}

Keywords: Chestnut plantations, Forest floor

\section{Introduction}

In temperate forest ecosystems the forest floor, or aboveground detritus, is one of the major reservoirs of the elements required for ecosystem metabolism and structural maintenance. Remezov and Pogrebnyak (1969) note that, in the course of the biological cycle, forest vegetation extracts the required nutrient elements from the soil and returns them to the soil, in proportions which are most favourable for its development; as a result of the succession of forest generations, the uppermost soil horizons become enriched in nutrient elements in the proportions required by the vegetation. That is, over a period of years the nutrients are concentrated where they are needed. This enrichment process depends directly on the release of nutrients from the litter.

As part of an integrated research program on the ecological structure, productivity, and biogeochemical cycling pathways of a chestnut plantation at Karies (Agio Oros mountain, Athos peninsula, northern Greece), we sought to quantify the standing crops, or pools, of nutrient elements and detrital biomass in the forest floor and to estimate the rate at which nutrient elements are lost from the forest floor.

\section{Materials and Methods}

\subsection{Organic Layers}

Soil sampling was conducted in October 2010. At each site, three circular sample plots $\left(314 \mathrm{~m}^{2}\right.$ each) were established. In each sample plot, three sampling points were randomly selected. At each sampling point, we measured the depth of the organic layer and manually extracted a litter sample. Sampling at woody, rocky, or disturbed locations was avoided. If sampling at a randomly selected location was not suitable, sampling was conducted $0.5 \mathrm{~m}$ in each of the cardinal directions (in the order north, south, east, west) until a suitable sampling location was encountered. Samples of forest floor were obtained by pressing a $625 \mathrm{~cm}^{2}$ steel sheet sampling frame $(10 \mathrm{~cm}$ deep) into the forest floor and collecting all organic material above the mineral soil. In each of these samples the horizons L and F, H were separated and carefully placed in plastic bags. The L horizon is composed of fresh or slightly discoloured, with no or weak breaking up, material. The F horizon is composed of medium to strongly fragmented material with many mycelia and thin roots and the $\mathrm{H}$ horizon is a humified amorphous material (Papamichos, 2006). Mineral soil was removed after successive sieving. All forest floor and samples were oven-dried to constant weight at $70^{\circ} \mathrm{C}$ and weighed. Litter subsamples were then ground in a Willey mill to pass a 40 mesh stainless steel sieve before being analyzed. 


\subsection{Chemical Analyses}

Litter subsamples were combusted in a muffle furnace at $520^{\circ} \mathrm{C}$ for $4 \mathrm{~h}$ and diluted with $\mathrm{HCI}$ in a $1: 1 \mathrm{ratio} \mathrm{v} / \mathrm{v}$ (Allen et al., 1974). The solutions were analyzed for total P colorimetrically using the phospomolybdenum blue method, and for total $\mathrm{Ca}, \mathrm{Mg}, \mathrm{Na}, \mathrm{K}, \mathrm{Fe}, \mathrm{Mn}, \mathrm{Cu}$, and $\mathrm{Zn}$ by atomic absorption spectroscopy. Total $\mathrm{N}$ was determined by Kjeldahl analysis. The organic matter was determined by loss on ignition at $540^{\circ} \mathrm{C}$ for $5 \mathrm{~h}$.

\section{Results and Discussion}

The total carbon storage (as represented by dry total litter weight) is significantly higher in our study than the bibliography-based expected values (Ganiatsas, 1963; 1975) (Fig. 1). Total litter weight in the forest floor was fairly stable throughout cutting ages. This fact suggests that the forest floor should soon be approaching a steady state.

An estimate of the composition of the leaf litter is given in Table 1. Over much of the cuttings' age, the amounts of nutrients, in general, were either approximately the same or greater than the bibliography-based expected values (Ganiatsas, 1963; 1975) (Fig. 2). A likely explanation for this is that there was more leaching due to higher rainfall in autumn 2010 than in the previous periods (Ganiatsas, 1963; 1975).

Litter profile gives some idea of the dynamics of litter decomposition and of elemental mobility (Table 1). Particularly noteworthy here are the decreasing concentration of magnesium through the litter profile and the increasing concentrations of ash-free organic matter, calcium, potassium, sodium, nitrogen, and phosphorus. This may have been due to the increased precipitation during the sampling period.

The increasing concentration of ash-free organic matter through the litter profile is attributable to metabolic losses of carbon dioxide and water, which decrease the carbon, hydrogen, and oxygen content of the decomposing material (Witkamp, 1971). Potassium increase is probably due to the high solubility of potassium compounds and the lower stability of monovalent vs. divalent cations in cation-exchange complexes. In general, however, in complex systems such as forest litter and soil, with many different exchange materials present and many biochemical processes taking place, it is difficult if not impossible to generalize on the exchange behaviour of cations on the basis of simple chemical arguments because the relative exchangeability varies considerably with the nature of the exchanger and the concentration of the solution (Wiklander, 1964).

It is reasonable to expect that the biologically critical elements nitrogen and phosphorus would tend to be retained and to increase in concentration during decomposition. Furthermore, nonsymbiotic nitrogen fixation probably adds to the original nitrogen content of the litter.

\section{Conclusion}

In brief, the forest-floor nutrient pools reported on here represent the result of a number of competing processes; principally litterfall, precipitation, leaching, microbial decomposition, and microbial immobilization, or uptake. For nitrogen, the additional processes of fixation, nitrification, and denitrification must be added. These processes result in a situation in which magnesium tend to be selectively concentrated in the Aoo layer of the forest floor, while ash-free organic matter, calcium, potassium, sodium, nitrogen, and phosphorus tend to be concentrated in the Ao layer of the forest floor.

\section{References}

Allen, S. E., Grimshaw, H.M., Parkinson, J. A., Quarmby, C. (1974). Chemical analysis of Ecological Material. Oxford: Black well Scientific Publications.

Ganiatsas, K. (1975). Ubersicht uber die Flora und die Vegetationverhaltnisse der Athos- Halbinsel. In Jordanov, D. and al. (eds): Problems of Balkan Flora and Vegetation, p.p 380-390. Sofia: Publishing House of the Bulgarian Academy of Sciences.

Ganiatsas, K. (1963). Vegetation and flora of the Holy Mountain peninsula - State of Athos. Thessaloniki, 509-678.

Papamichos, N. (2006). Forest Soils. Aristotle University of Thessaloniki, Greece (in Greek).

Remezov, N. P., Pogrebnyak, P. S. (1961). Decomposition of Forest Litter and the Cycle of Elements in an Oak Forest. For. Soil Sci., 703-711.

Wiklander, L. (1964). Cation and Anion Exchange Phenomena, in Chemistry of the Soil. $2^{\text {nd }}$ ed. New York: Reinhold Publishing Corporation.

Witkamp, M. (1971). Soils as Components of Ecosystems. Annu. Rev. Ecol. Systemat., 85-110. http://dx.doi.org/10.1146/annurev.es.02.110171.000505 
Table 1. Change in concentration of litter components through the litter profile

\begin{tabular}{|l|l|l|l|l|l|l|l|}
\hline Layer & $\begin{array}{l}\text { Ash-free } \\
\text { organic matter \% }\end{array}$ & $\begin{array}{l}\mathrm{Ca} \\
\mathrm{mg} / \mathrm{gr}\end{array}$ & $\begin{array}{l}\mathrm{Mg} \\
\mathrm{mg} / \mathrm{gr}\end{array}$ & $\begin{array}{l}\mathrm{K} \\
\mathrm{mg} / \mathrm{gr}\end{array}$ & $\begin{array}{l}\mathrm{Na} \\
\mathrm{mg} / \mathrm{gr}\end{array}$ & $\begin{array}{l}\mathrm{N} \\
\mathrm{mg} / \mathrm{gr}\end{array}$ & $\begin{array}{l}\mathrm{P} \\
\mathrm{mg} / \mathrm{gr}\end{array}$ \\
\hline Aoo & 68.42 & 12.77 & 5.23 & 2.81 & 0.50 & 1.22 & 0.923 \\
\hline Ao & 89.25 & 17.73 & 3.86 & 3.32 & 0.59 & 1.23 & 0.995 \\
\hline
\end{tabular}

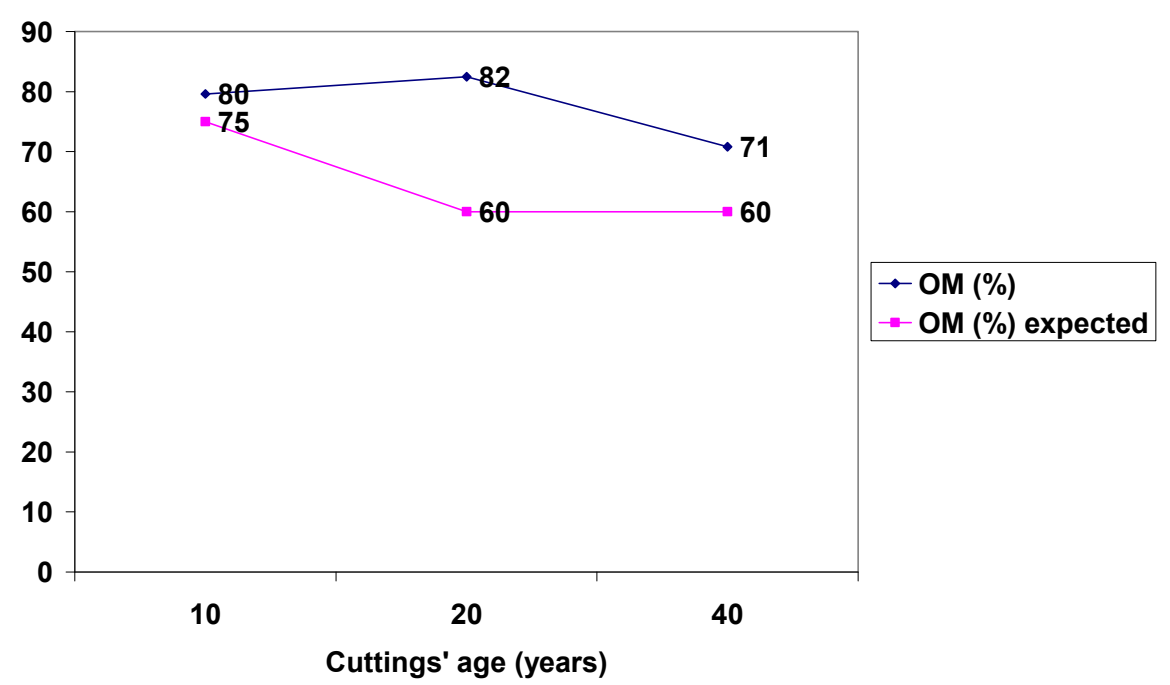

Figure 1. Total oven-dry weight of forest-floor litter (\%)
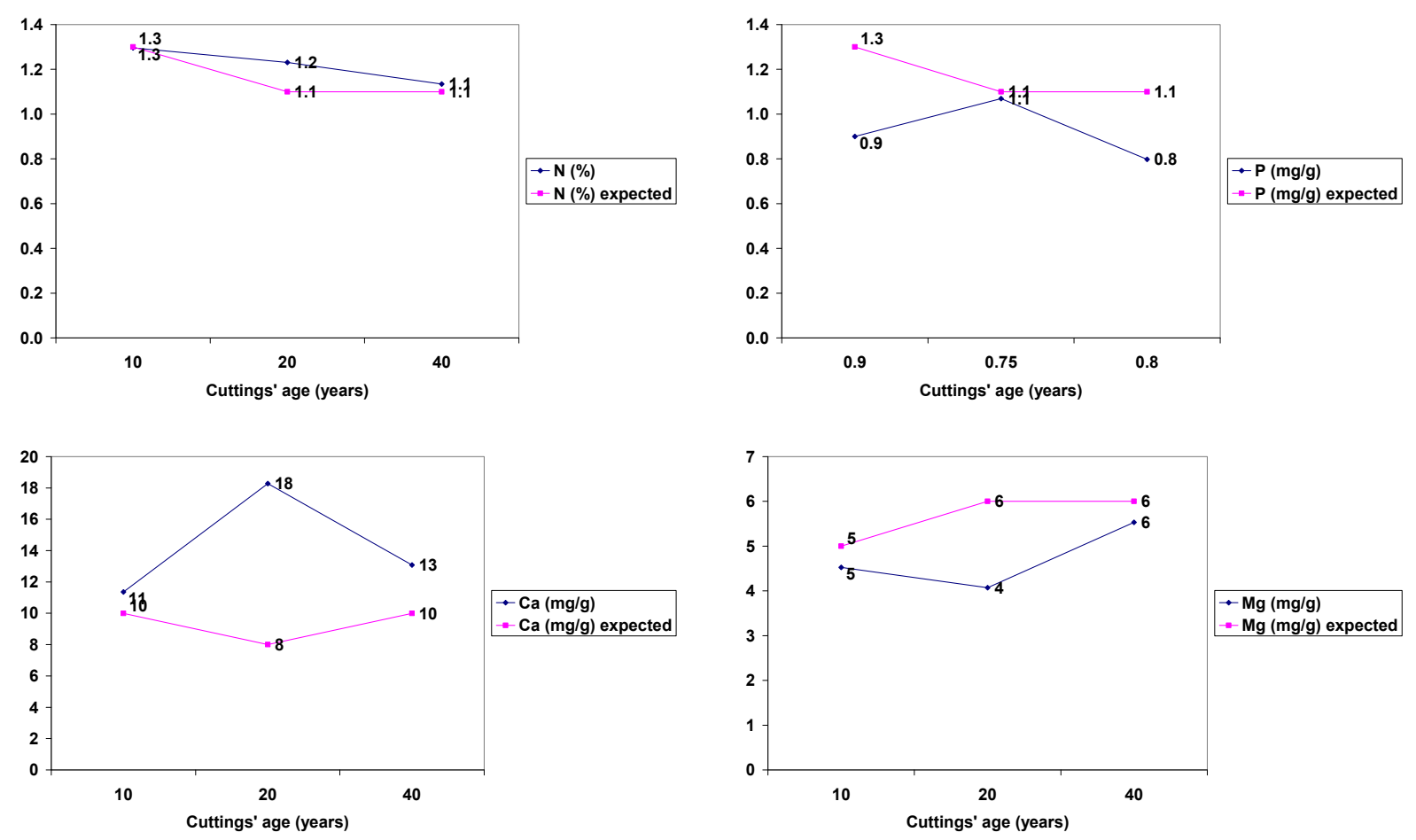

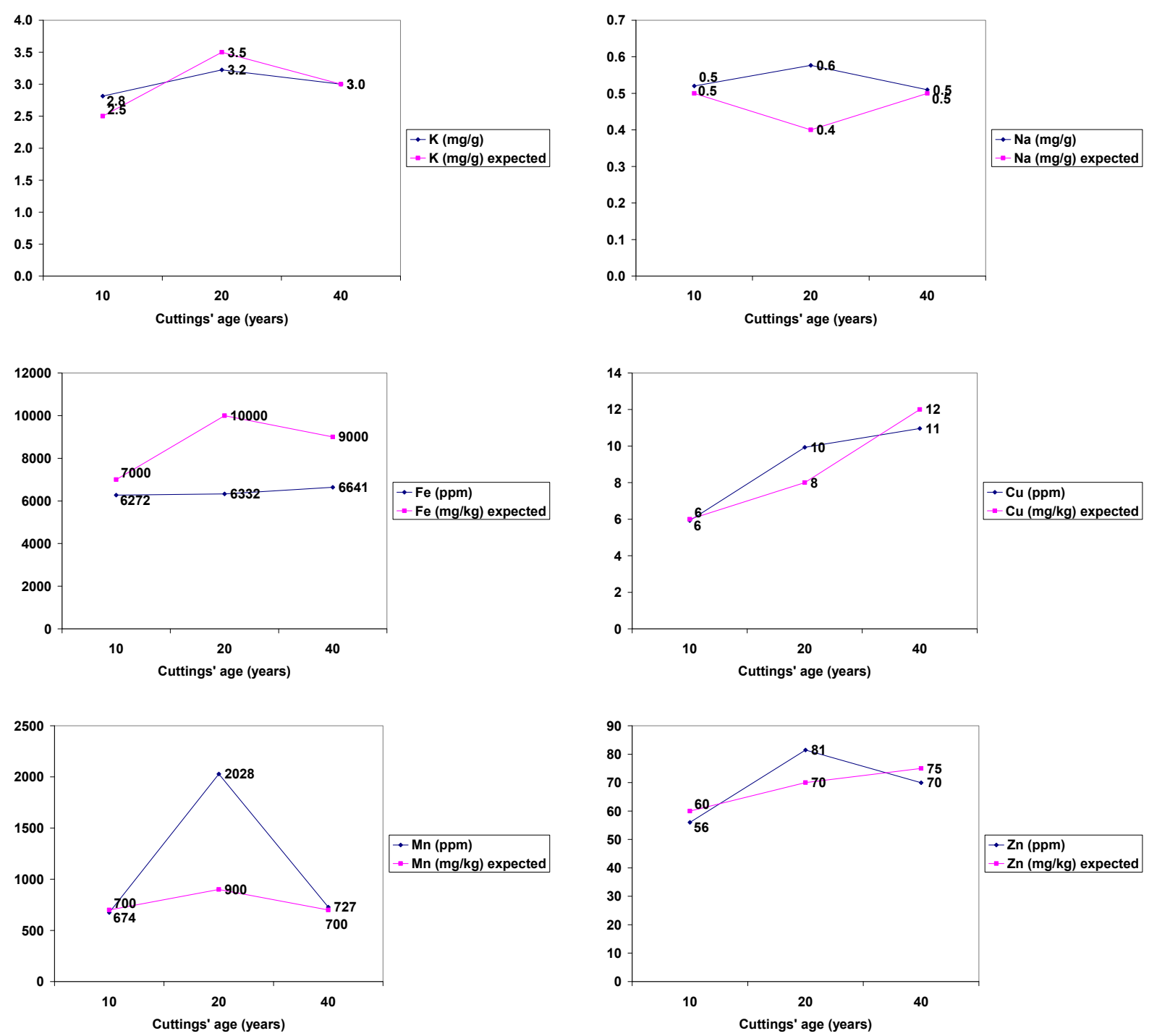

Figure 2. Total forest floor content of selected nutrients 